\title{
Movement of gray snapper Lutjanus griseus among subtropical seagrass, mangrove, and coral reef habitats
}

\author{
Jiangang Luo ${ }^{1, *}$, Joseph E. Serafy ${ }^{1,2}$, Su Sponaugle ${ }^{1}$, Paul B. Teare ${ }^{1}$, \\ David Kieckbusch ${ }^{3}$
}

\author{
${ }^{1}$ University of Miami, Rosenstiel School of Marine and Atmospheric Science, Division of Marine Biology and Fisheries, \\ 4600 Rickenbacker Causeway, Miami, Florida 33149, USA \\ ${ }^{2}$ NOAA Fisheries, Southeast Fisheries Science Center, 75 Virginia Beach Drive, Miami, Florida 33149, USA \\ ${ }^{3}$ Milian, Swain \& Associates, Inc. 2257 Vista Parkway, Ste. 19, West Palm Beach, Florida 33411, USA
}

\begin{abstract}
Many fishes are thought to make diel, seasonal and/or ontogenetic migrations among seagrass, mangrove, and coral reef habitats. However, most evidence of such movement has been inferred from density and size structure differences among these habitats in tropical waters. The aim of the present study was to directly evaluate multiple habitat use by an ecologically and economically important reef fish, the gray snapper Lutjanus griseus, in subtropical waters. An integrated set of activities was conducted, including tagging and tracking of individuals and underwater video photography to examine the spatial and temporal dynamics of movements among neighboring mangrove, seagrass, and coral reef habitats in the northern Florida Keys, USA. Results of ultrasonic acoustic and mini-archival tagging indicated that $L$. griseus exhibits: (1) a distinct diel migration pattern, whereby shallow seagrass beds are frequented nocturnally and mangroves and other habitats with complex structure are occupied diurnally, and (2) bay-to-ocean movement, occurring during the known spawning season of $L$. griseus in this region. Video photography confirmed diel movement among seagrass and mangrove habitats. Results of this subtropical study corroborate direct and indirect evidence obtained in tropical waters of multiple inshore habitat use by L. griseus, as well as its seasonal movement into or towards offshore reefs. For resource managers charged with designing and implementing management plans for subtropical coastal habitats and fisheries, our findings provide direct support for the strategy of conserving both inshore seagrass and mangrove habitats as well as offshore coral reefs.
\end{abstract}

KEY WORDS: Diel · Seasonal · Gray snapper · Movement · Mangrove $\cdot$ Seagrass $\cdot$ Reef $\cdot$ Acoustic tagging $\cdot$ Underwater video

\section{INTRODUCTION}

The high biodiversity and productivity of tropical and subtropical coral reef habitats may be partially dependent on the linkages among adjacent shallow water habitats. Tropical marine seagrass beds are widely viewed as nurseries and/or feeding areas for many coral reef fishes (e.g. Weinstein \& Heck 1979, Orth et al. 1984), and mangrove habitats are increas- ingly implicated as playing a similar role in support of coral reef fish populations and fisheries (e.g. Laegdsgaard \& Johnson 2001, Ley \& McIvor 2002, Mumby et al. 2004). While many reef fishes are thought to make diel, seasonal, or ontogenetic migrations among seagrass, mangrove, and reef habitats (e.g. Starck \& Davis 1966, Robblee \& Zieman 1984, Sedberry \& Carter 1993, Ogden 1997), most evidence of such movements has been qualitative or inferred from density and size 
structure (e.g. Cocheret de la Morinière et al. 2002, Faunce \& Serafy 2007, Nagelkerken 2007), dietary isotopes, and gut content analysis (Harrigan et al. 1989, Cocheret de la Morinière et al. 2003) or from otolith microchemistry (Chittaro et al. 2004). Recent work in Atlantic and Caribbean waters strongly suggests mangrove and seagrass 'back-reef' areas are a critical ontogenetic link in the life cycle of a number of coral reef fishes, serving as important nurseries for juveniles (e.g. Nagelkerken et al. 2000, Serafy et al. 2003, Mumby et al. 2004, Adams et al. 2006, Dorenbosch et al. 2007). Three recent reviews examining mangroves as fish habitat (Faunce \& Serafy 2006, Nagelkerken 2007, Nagelkerken et al. 2008) have noted the dearth of direct evidence of fish movement among mangroves and other coastal habitats. Such species-specific data are needed to begin to quantify the contributions made by adjacent, shallow-water habitats in the life cycles and sustainability of managed fish species (Beck et al. 2001).

Nearshore mangrove and seagrass habitats along the southern Florida (USA) coast likely contribute substantially to regional reef fish resources, which support a tourist industry and recreational and commercial fisheries valued in billions of dollars (Bohnsack \& Ault 1996). Although southern Florida encompasses extensive seagrass meadows, mangrove shorelines and coral reefs, both commercial and recreational fishing is permitted within the boundaries of these protected areas (Florida Keys National Marine Sanctuary, FKNMS; Biscayne National Park, BNP). A stock assessment a decade ago determined that 13 of 16 grouper, 7 of 13 snapper, and 2 of 5 grunt species have been chronically overexploited since at least the late 1970s (Ault et al. 1998). Most of these species utilize nearshore habitats during some portion of their life cycle. Thus, in addition to direct losses to fishing, populations may be suffering higher mortality due to regional habitat degradation or loss. There is a need for unambiguous data for evaluating reef fish dependence on adjacent 'off-reef' habitats.

The purpose of our study was to directly evaluate multiple habitat use by an ecologically and economically important reef fish, the gray snapper Lutjanus griseus, in subtropical waters (Starck 1971). Data collected from over one-thousand $60 \mathrm{~m}^{2}$ belt-transects within Biscayne Bay, Florida, over 10 consecutive (alternating wet/dry) seasons have demonstrated significant seasonal and spatial variation in the densities and size structures of several reef fish species, including gray snapper (Faunce \& Serafy 2006, Serafy et al. 2007). While the evidence is circumstantial, mangrove habitats appear to have 2 primary ecological functions with regard to L. griseus. For all life stages, mangroves are likely daytime 'resting' areas_complex, relatively 'food-poor' habitats that afford a measure of protection from predation, but which are vacated at night as individuals forage in adjacent, relatively 'food-rich' seagrass beds (Rooker \& Dennis 1991, Nagelkerken et al. 2000). High densities of large ( $>25 \mathrm{~cm})$, presumably mature, individuals suggest that, in addition to serving as daytime resting areas, these habitats may serve as 'staging areas' for adult congregation prior to seasonal spawning migrations to offshore reefs (Sheridan \& Hays 2003). Adult gray snapper also are found in resting schools on coral reefs (Bohnsack et al. 1999), and young gray snapper are frequently collected by shrimp trawlers in seagrass beds at night (Serafy et al. 1997). Further quantitative data are needed to substantiate this scenario of differential diel and seasonal use of multiple habitats by different life stages. Here, we aimed to define for gray snapper, at or near size-atmaturity, the scope and timing of: (1) diel migrations in and out of mangroves and (2) bay-to-ocean movement.

\section{MATERIALS AND METHODS}

We quantified gray snapper Lutjanus griseus movement among 3 coastal habitats in southern Florida by deploying 2 tag types, ultrasonic acoustic and miniarchival tags, and an underwater video monitoring system. The subsequent distributions of tagged fish were monitored by both fishery-independent (acoustic telemetry) and fishery-dependent means. Fisherydependent monitoring included data reporting by local recreational and commercial fishers as well as the return of mini-archival tags from any tagged fish encountered.

Study area. The present study was conducted in the vicinity of Biscayne Bay, Florida, where all 3 habitat types (mangrove forests, seagrass beds, coral reefs) were easily accessible (i.e. within $5 \mathrm{~km}$ of each other) (Fig. 1). We selected several study sites based on data from our ongoing mangrove fish survey, available benthic habitat data, and proximity to at least 2 passes linking Biscayne Bay and the Atlantic shelf. The 2 mangrove sites, MG1 and MG2, are leeward of the barrier islands of Sands Key and Elliott Key, which have shorelines entirely lined with red mangroves Rhizophora mangle (Fig. 1). The habitat immediately adjacent to the bayside mangrove shoreline is mostly dense seagrass beds dominated by turtle grass Thalassia testudimum. The water depths range from $0.5 \mathrm{~m}$ near the shoreline to $1.5 \mathrm{~m}$ about $500 \mathrm{~m}$ offshore. The 2 islands (Sands Key and Elliott Key) are separated by a relatively deeper (maximum $4 \mathrm{~m}$ ) cut (Sands Cut), which is $\sim 50 \mathrm{~m}$ wide and $200 \mathrm{~m}$ long. The lower portions of the cut are lined with eroded limestone ledges and cavities, providing complexity and potential shel- 
ter for fish. Immediately surrounding Sands Cut, on the bay and ocean sides, are dense seagrass beds. The shoreline at MG2 is more or less linear, while at MG1 it is a more complex cove and island formation with a manmade canal leading to a small circular embayment known as the 'Key Hole' (Fig. 2). OR1 and OR2 are offshore coral reef sites in the forereef habitat located between the 2 acoustic receiver arrays described

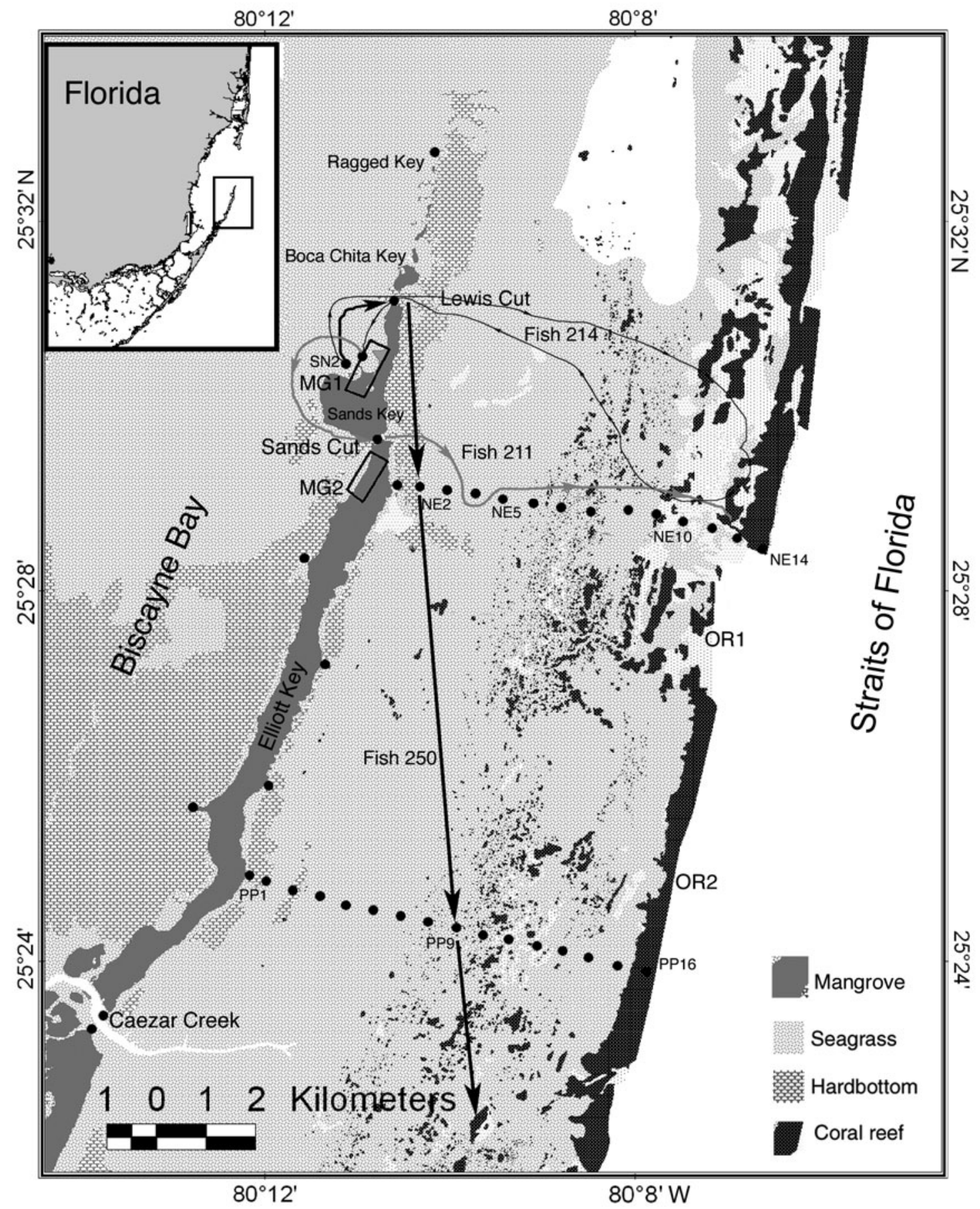

Fig. 1. Lutjanus griseus. Map of study area showing major benthic habitat types: mangrove, seagrass, hardbottom, and coral reef. (hardbottom belongs to coral reef habitat type). The shorelines of the islands are forested with red mangroves. Study sites are marked as MG1 (Mangrove Site 1) and MG2 (Mangrove Site 2) for inshore sites, and OR1 (Ocean Reef Site 1) and OR2 (Ocean Reef Site 2) for offshore reef sites. (๑) locations of automated acoustic receivers. Two lines of receivers extended from inshore to offshore as NE1 to NE14 (NE for north Elliott Key) and PP1 to PP16 (PP for Petro Point). Schematic offshore movement tracks of 3 acoustically tagged gray snappers Lutjanus griseus are shown as thin gray line (Fish 211), thin black line (Fish 214), and thick black line (Fish 250) 
below. The relationship of mangrove, seagrass, and reef habitats is typical of nearshore areas in the wider Caribbean, with the exception of the natural and manmade passes, where exposed limestone cavities may provide additional shelter for fishes (i.e. caves, holes, and ledges may provide a similar function as mangroves).

Acoustic tagging and tracking. Acoustic tagging and tracking is currently recognized as one of the most direct methods of measuring the movement patterns of

a

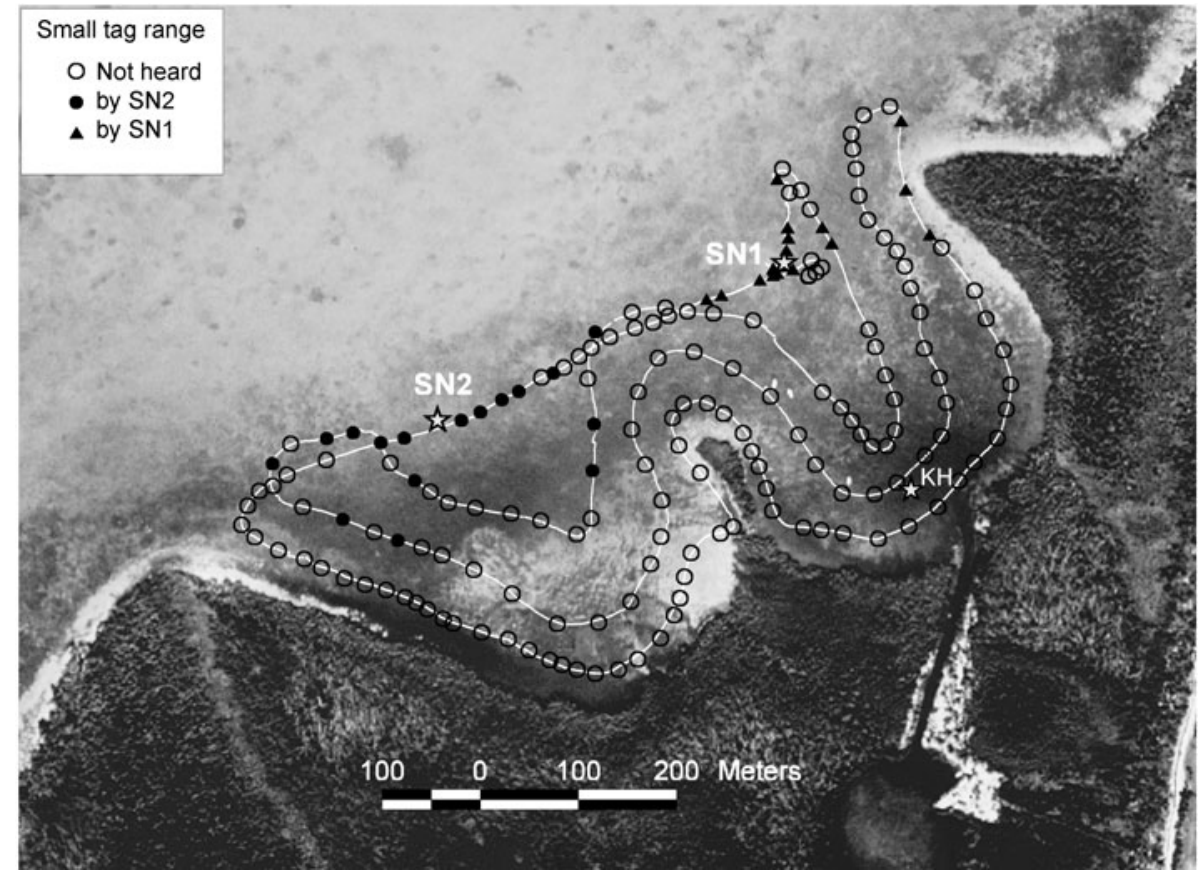

b

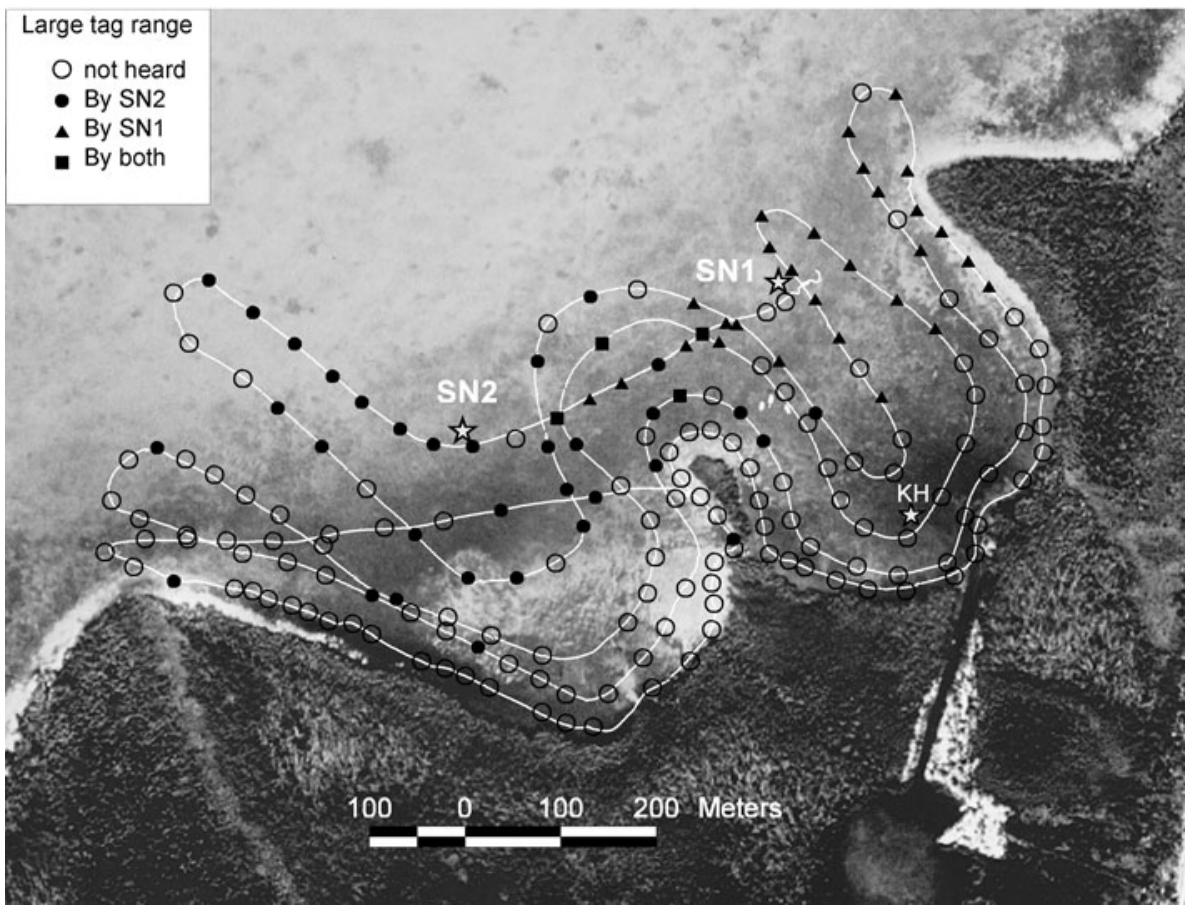

Fig. 2. Lutjanus griseus. Range test results for receivers at MG1 site using: (a) small versus (b) large transmitters. 浨: receiver; $\mathbf{\Delta}$ : detection by receiver $\mathrm{SN}_{1}$; : detection by receiver $\mathrm{SN2}$; detection by both receivers; O: undetected locations. A third receiver $(\mathrm{KH})$ was added near the Key Hole 1 yr after the range test 
mobile fishes (e.g. Jorgensen et al. 2006, Taylor et al. 2006, Meyer et al. 2007). We deployed ultrasonic tags to monitor the diel and seasonal movements of gray snapper using stationary tracking techniques. Automated acoustic telemetry (AT) technology afforded an opportunity to monitor a relatively remote area of the coastal ocean on a continuous basis for the presence of tagged fish without requiring the constant presence of researchers. Success of such an operation depends on the strategic orientation of the hydrophone 'listening' stations to allow continuous collection of transmitted data on mesoscale movement patterns over extended periods of time (Heupel et al. 2006). Our AT system consisted of an array of data-logging hydrophone stations that were located along mangrove shorelines, seagrass beds, oceanic channels, patch reefs, and barrier reefs in the vicinity of Biscayne Bay, Florida (Fig. 1). Two lines of acoustic receivers, separated by about $500 \mathrm{~m}$, were positioned from Elliott Key seaward to the forereef to monitor north-south movement of fish if they passed through the lines. Maintenance of the offshore acoustic 'fences' was shared with researchers examining bonefish Albula vulpes movement (Larkin et al. 2008). The first line started at north Elliott Key (NE1 to NE14), and the second line started at Petro Point (PP1 to PP16). Receivers were also located at Caesar's Creek, Sands Cut, Lewis Cut, and Ragged Key to monitor bay-to-ocean movement or vice versa. It is important to note that there are many possible pathways that were not monitored by any receivers, such as the large openings north of Boca Chita Key and north of Ragged Key. Initially, 2 receivers (SN1 and SN2) were set to monitor diel movements between mangrove and seagrass habitats at MG1 (Fig. 2). Later, a third receiver $(\mathrm{KH})$ was added at the site near the Key Hole to monitor movement near the shoreline.

Seventeen gray snapper were fitted with VEMCO Model V8SC (small tag) or V13 (large tag) coded acoustic transmitting pinger tags operating on a 69 $\mathrm{kHz}$ frequency. Pingers were pre-programmed with 10 to $30 \mathrm{~s}$ (for V8SC) and 20 to $60 \mathrm{~s}$ (for V13) random delays between individual transmissions, allowing the tags to transmit for a minimum period of at least 135 (V8SC) or $155 \mathrm{~d}$ (V13) post-activation. A VEMCO Model VR-2 hydrophone and data logging stations were used to monitor snapper movements. Upon reception of a signal, the data logger recorded the time and identified the tag number by its unique transmission pattern. Data were periodically downloaded onto a portable computer using VEMCO's hardware and software system interface.

Snapper were captured from mangrove habitats by hook-and-line and transferred to a holding tank with a calming concentration of clove oil. The tag was surgically implanted in the abdominal cavity of the fish, with the ratio of tag:body mass held at $<3 \%$ (Winter 1983, Marty \& Summerfelt 1986). Tags were inserted through a $1 \mathrm{~cm}$ incision along the ventral midline between the pelvic girdle and the anal vent. Incisions were closed using a medical grade surgical stapler. Following transmitter attachment, fish were placed into a recovery tank for observation before release at the original capture location. All fish were further identified with conventional T-bar anchor tags.

To assess the detection range of individual receivers at their respective locations in the array, we towed an activated tag in predetermined patterns around the receiver stations. The tag was deployed from a boat, and weights were used to keep the transmitter near (about $6 \mathrm{~cm}$ above) the substrate. The location of the vessel was recorded every second by means of a laptop computer connected to a WAAS-enabled geographic positioning system (GPS). To match the time of detection of the acoustic tag at each receiver with the GPS locations, all receivers were initially synchronized within 1 s using official US Eastern Standard Time (EST; www.time.gov). To assess potential variance or 'time drift' of individual receiver clocks, a VEMCO VR28 tracking system was used to record transmission time of 10-ping sequences emitted immediately adjacent to each receiver. This provided a known 'time stamp' on each receiver and allowed correction for time drift during data analysis. The range test was conducted in November 2004. Considering the constant salinity $(35.5 \pm 0.5 \mathrm{psu})$, moderate temperature range $\left(20\right.$ to $\left.30^{\circ} \mathrm{C}\right)$ and shallow depth $(0.5$ to $1.5 \mathrm{~m})$ of the nearshore environment, seasonal differences in the range are assumed to have been very small. Thus, range tests were not conducted in other seasons. In shallow water, the most important factor affecting detection range is weather (wind, rain), but variation in weather conditions should not influence results summed over a long time period.

Based on the range test results, we tabulated all signals from all tags detected by Receiver SN2 to generate an overview of signal detection as function of hour (EST). We then binned these signals into hourly time series, and applied Fast Fourier Transformation (FFT) analysis to detect periodicity in the time series using IDL (Interactive Data Language; www.RSInc.com).

Archival tagging. Mini-archival tags were surgically implanted in the abdomen of 44 larger fishes (26 to $45 \mathrm{~cm}$ total length), each also tagged with a conventional (T-bar anchor) tag. The archival tag was $11 \mathrm{~mm}$ $\times 32 \mathrm{~mm}$, and weighed about $2 \mathrm{~g}$ in water (LTD1100; www.Lotek.com). The procedure for implanting the tag was the same as for the sonic tag (see previous subsection). The archival tag retrieves up to 66000 timed records of temperature and depth and is automatically adjusted to record for the full length of the mission ( $>2$ 
yr). The automatic time extension recording is based on the doubling time interval method. The logger begins recording at a base sampling interval of 1 sample every $14 \mathrm{~s}$. When its memory is full, the logger doubles its sampling interval and continues recording, overwriting the previously recorded samples, and when its memory is filled at that sampling interval it doubles its sampling interval again. The process can be repeated almost indefinitely for the life of battery $(>2 \mathrm{yr})$. We also measured water temperature in situ over the range of nearshore habitats. Because there were no sharp gradients in water temperature over our shallow sampling area and temperature primarily varied with the day/night cycle, for brevity, we have omitted presentation of both in situ and tag-measured temperature results.

Underwater video. We built a 16-channel underwater video surveillance system with 16 IR LED cameras to monitor fish movement between the mangrove shoreline and adjacent seagrass bed during day and night hours. The cameras were connected via 16 underwater video cables to a digital video recorder housed in a waterproof case, all powered via 2 power cables attached to two $12 \mathrm{~V}$ batteries. After a successful trial to test the feasibility of monitoring snapper in multiple habitats with the camera system, 2 overnight monitoring deployments were conducted. The first overnight video deployment (Deployment 1) was conducted from 16:30 h on May 5 to 14:00 h on May 6, 2004. The second deployment (Deployment 2) was planned from 12:30 h on May 16 to 12:00 h on May 17.
2005; but batteries failed at 8:00 h. In Deployment 1, 16 cameras were set up in 2 rows of 8 cameras, one parallel to the edge of the mangrove prop roots and the other about $10 \mathrm{~m}$ seaward of the prop roots in the adjacent seagrass habitat. Cameras were pointed along (i.e. parallel to) the mangrove habitat, with each camera facing the back of the camera preceding it, so that all fish entering or leaving the mangrove habitat would be recorded. The configuration in seagrass habitat was identical to its counterpart at the mangrove edge. In Deployment 2, only 8 cameras were used, and these were oriented in 2 rows of 4 cameras. The video images were analyzed frame-by-frame to count every gray snapper detected on the video. Data were recorded as the number of gray snapper observed per minute per camera. During the day the IR LED cameras were able to detect fish at a range of $\sim 1 \mathrm{~m}$, while at night detection was $\sim 0.5 \mathrm{~m}$.

\section{RESULTS}

\section{Acoustic tracking}

We tagged 17 gray snapper Lutjanus griseus with acoustic transmitters from June 3, 2004 to May 25, 2005 (Table 1) and tracked these using an AT system. We detected all 14 of the tagged fish released at MG1 within our mangrove habitat, but never detected any of the 3 tagged fish released at the reef site (OR2). Of those released at MG1, 9 fish were released during the

Table 1. Lutjanus griseus. Gray snappers tagged with acoustic tags. Location of release sites and receiver sites are shown in Figs. 1 \& 2. TL: total length; dates given in the format mm/dd/yy. Tags numbered 211-220 are V13 (large); tags numbered 241-250 are V8SC (small)

\begin{tabular}{|c|c|c|c|c|c|c|c|c|c|c|c|}
\hline $\begin{array}{l}\text { Fish } \\
\text { (tag } \\
\text { no.) }\end{array}$ & $\begin{array}{l}\text { Date of } \\
\text { release }\end{array}$ & $\begin{array}{l}\text { Site of } \\
\text { release }\end{array}$ & $\begin{array}{c}\text { Fish TL } \\
(\mathrm{cm})\end{array}$ & $\begin{array}{c}\text { No. } \\
\text { by } \\
\text { SN1 }\end{array}$ & $\begin{array}{l}\text { ected: } \\
\text { by } \\
\text { SN2 }\end{array}$ & $\begin{array}{c}\text { Days of } \\
\text { last } \\
\text { signal }\end{array}$ & $\begin{array}{c}\text { Date of } \\
\text { last } \\
\text { signal }\end{array}$ & $\begin{array}{l}\text { Days of } \\
\text { last signal } \\
\text { at M1 }\end{array}$ & $\begin{array}{l}\text { Last } \\
\text { date } \\
\text { at cut }\end{array}$ & $\begin{array}{c}\text { Days } \\
\text { offshore }\end{array}$ & $\begin{array}{c}\text { Date } \\
\text { offshore }\end{array}$ \\
\hline 245 & 06/03/04 & MG1 & 33.4 & 231 & 0 & 91 & 09/03/04 & 53 & 09/03/04 & 0 & \\
\hline 242 & 06/08/04 & MG1 & 24.9 & 37 & 144 & 6 & $06 / 14 / 04$ & 6 & & 0 & \\
\hline 243 & 06/08/04 & MG1 & 25.7 & 10 & 512 & 13 & 06/21/04 & 13 & & 0 & \\
\hline 244 & 06/08/04 & MG1 & 24.0 & 0 & 312 & 4 & 06/12/04 & 4 & & 0 & \\
\hline 250 & 06/08/04 & MG1 & 31.7 & 409 & 22195 & 88 & 09/03/04 & 87 & 09/03/04 & 1 & 09/03/04 \\
\hline 246 & $07 / 22 / 04$ & OR2 & 29.9 & 0 & 0 & 0 & & 0 & & 0 & \\
\hline 247 & $07 / 22 / 04$ & OR2 & 28.0 & 0 & 0 & 0 & & 0 & & 0 & \\
\hline 249 & $07 / 22 / 04$ & OR2 & 32.6 & 0 & 0 & 0 & & 0 & & 0 & \\
\hline 212 & $11 / 10 / 04$ & MG1 & 30.8 & 6873 & 37122 & 187 & $05 / 17 / 05$ & 187 & & 0 & \\
\hline 216 & $11 / 10 / 04$ & MG1 & 29.3 & 1 & 32 & 138 & 03/29/05 & 138 & & 0 & \\
\hline 217 & $11 / 10 / 04$ & MG1 & 30.2 & 511 & 4570 & 165 & 04/25/05 & 165 & & 0 & \\
\hline 218 & $11 / 10 / 04$ & MG1 & 26.6 & 173 & 8185 & 336 & $10 / 13 / 05$ & 336 & 08/10/05 & 0 & \\
\hline 220 & $11 / 20 / 04$ & MG1 & 27.4 & 2045 & 3178 & 208 & 06/07/05 & 208 & $06 / 07 / 05$ & 0 & \\
\hline 211 & 05/09/05 & MG1 & 35.8 & 167 & 4345 & 88 & 08/05/05 & 75 & $07 / 23 / 05$ & 13 & $07 / 24 / 05$ \\
\hline 219 & 05/09/05 & MG1 & 30.1 & 0 & 411 & 75 & $07 / 23 / 05$ & 75 & 07/23/05 & 0 & \\
\hline 241 & 05/09/05 & MG1 & 27.9 & 57 & 249 & 1 & 05/15/05 & 1 & & 0 & \\
\hline 214 & $05 / 25 / 05$ & MG1 & 32.8 & 0 & 2833 & 158 & $10 / 28 / 05$ & 150 & $10 / 28 / 05$ & 1 & 08/26/05 \\
\hline
\end{tabular}


wet season (May to October) and 5 fish were released during the dry season (November to April). Ten of the 14 fish released at MG1 remained at the site for at least $50 \mathrm{~d}$ and for as long as $336 \mathrm{~d}$. Four fish that stayed at MG1 for $<14 \mathrm{~d}$ were released during the wet season (May to October). All 5 fish released in the dry season (November to April) remained at MG1 for at least 4 mo. Seven fish were detected at the bay-to-ocean pathways (the cuts), and 3 of these were also detected by offshore receivers. All offshore migrations were detected from June to October.

The range tests at MG1 indicated that the receivers (SN1 and SN2) could detect most signals from both tag types (large and small) when the tagged fish were in the seagrass areas. Receiver SN2 had a longer range than Receiver SN1, but neither could detect signals from the small tag (V8SC) when tagged fish were near the mangrove shoreline, except for the northwestern corner (Fig. 2). There were a few places where seagrass positions were not detected and a few detections near the mangrove shoreline, but these were intermittent events. Thus, continuous detections of acoustically tagged snapper would indicate that fish were in the seagrass habitat in the vicinity of the receivers. Continuous lack of detections would indicate that fish were not in the seagrass habitat around the receivers, and were most likely in the mangrove habitat (since the entire cove is surrounded by mangroves) or had moved out of the area.

In total, 84983 signals were detected by SN2, while only 10744 signals were detected by SN1, due to the distribution of tagged snapper; therefore, we concentrated further analysis on SN2. Summarizing the signals from all of the tags detected by Receiver SN2 into 4 seasonal hourly frequency plots (Fig. 3) revealed that Lutjanus griseus exhibits a diel pattern of habitat utilization, moving daily between primarily seagrass habitat at night and mangrove and other habitats (channel ledges and cavities, if available) during the day. This diel movement was the strongest signal in the power spectra $\left(1\right.$ cycle $\left.\mathrm{d}^{-1}\right)$ from the Fourier analysis of the hourly time series (Fig. 3e). Although this diel pattern of fish habitat utilization was somewhat variable and fish periodically moved into seagrass habitats during the day, they generally spent more time in seagrass habitats during the night. Diel differences in the number of snapper detected by SN2 appeared to be somewhat more pronounced in winter and spring than in fall (Fig. 3), but generally fish spent the least amount of time in seagrass beds during the mid-afternoon hours (14:00 to 16:00 h).

Detections by receivers located at bay-to-ocean pathways (the cuts) and by the offshore acoustic fences provided evidence of seasonal movement of gray snapper. Seven of 14 snapper (50\%) tagged in the bay were detected by receivers at either Lewis Cut or Sand Cut, and 3 of these $(21 \%)$ were also detected by offshore receivers (Table 1). The first fish, Fish 250, left MG1 at around 1:00 h on September 4, 2004, and was detected at Lewis Cut at around 9:40 h on the same day, at NE2 at 1:00 h, and at PP9 at 3:30 h on September 5 (Figs. 1 $\& 4 \mathrm{a})$. The estimated swimming speed for this fish from NE2 to PP9 was $\sim 0.9 \mathrm{~m} \mathrm{~s}^{-1}$, i.e. $\sim 2.8$ body lengths (BL) $\mathrm{s}^{-1}$.

The second fish, Fish 211, was caught on May 9, 2005. Although it had a surgical staple on its abdomen, we could find neither an acoustic nor an archival tag in the fish, so we implanted a new acoustic tag in this individual. After release, the fish was detected at MG1 every day for $75 \mathrm{~d}$ until it left the site for the reef (Figs. $1 \& 4 \mathrm{~b})$. On the way to the reef, the fish was first detected at Sands Cut at 23:58 h on July 23, and it remained in the cut for about $1 \mathrm{~d}$ before being detected by the 7 receivers on the northern receiver fence on the night of July 24 . Thereafter, the fish was detected at the reef by Receivers NE12 and N13 for about $13 \mathrm{~d}$. The estimated swimming speed for this fish based on a straight line from Sands Cut to NE12 was about $0.4 \mathrm{~m}$ $\mathrm{s}^{-1}\left(\sim 1.1 \mathrm{BL} \mathrm{s}^{-1}\right)$.

The third fish, Fish 214, was detected daily by Receiver SN2 for the first 36 d after release. It was never detected by Receiver SN1, and was only detected in a few instances by the $\mathrm{KH}$ receiver. From July 1 to 19, 2005, the fish went undetected, until it was detected at Lewis Cut on July 20. For the next month, the fish was frequently detected by Receiver SN2 and periodically by the receiver at Lewis Cut. On the night of August 26, the fish was detected by Receivers NE11 and NE12 on the reef, and, $6 \mathrm{~h}$ later, the fish was detected by the receiver at Lewis Cut. Two days later, the fish was detected by SN2 at MG1 (Figs. 1 \& 4c). From then on, the fish was detected frequently by Receiver SN2 and the receiver at Lewis Cut until we terminated the deployment on October 28, 2005. Overall, this fish was detected by the receiver at Lewis Cut on 16 different days, but only detected by receivers at the reef on a single day. Estimated swimming speed for this fish during its nearshore return on the night of August 26 was $0.4 \mathrm{~m} \mathrm{~s}^{-1}\left(\sim 1.2 \mathrm{BL} \mathrm{s}^{-1}\right)$.

\section{Archival tags}

Forty-four fish surgically implanted with miniarchival tags were released between November 2003 and October 2004. Eight of these tags were returned by recreational fishers, with days at large ranging from 11 to 197 d, and all recapture locations were at or near Sands Cut (Table 2), except for 1 tag, where the fish was recaptured over a reef. Of the 8 tags recovered, we 
were able to download the data directly from 5 and indirectly from 3 after sending them to the manufacturer for data downloading due to battery failure. All tags contained reasonable data except 1 tag that was accidentally reset by the angler when the tag was placed alongside a magnetic screwdriver in his pocket.
Fish 41 was out for 18 mo, but its battery failed 4 mo after deployment.

The depth distributions from 6 archival tags revealed how Lutjanus griseus moves vertically in different habitats (Fig. 5). In general, the mangrove and seagrass habitats in our study area have depth ranges of $<2 \mathrm{~m}$, and the
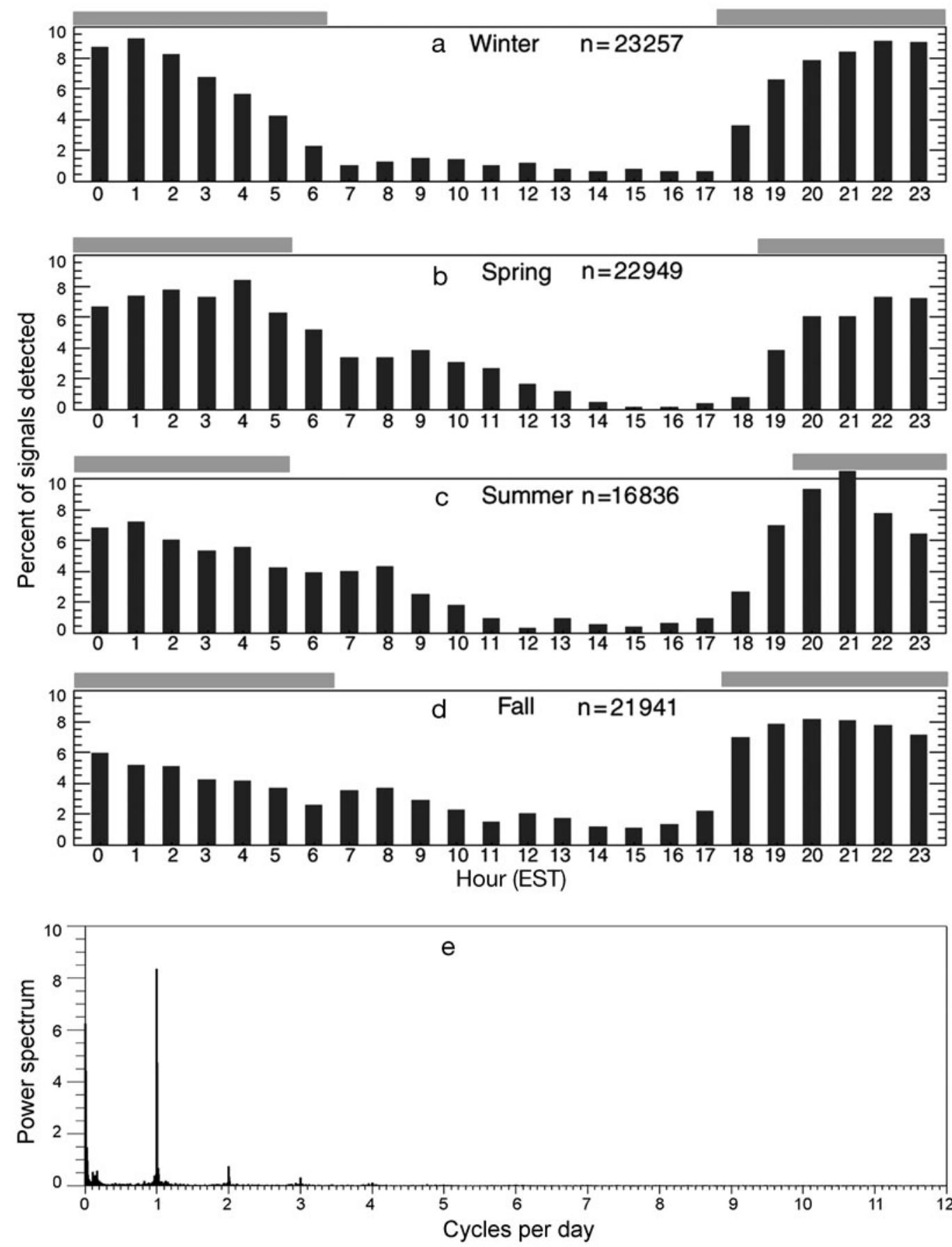

Fig. 3. Lutjanus griseus. Hourly distribution of signals from all tags detected by Receiver SN2 for: (a) winter (January to March); (b) spring (April to June); (c) summer (July to September); (d) fall (October to December). Total number of signals for each season is indicated (n). The sum of the detections per season was $100 \%$. Horizontal gray bars indicate the nighttime period. (e) The power spectrum of the Fast Fourier Transformation 


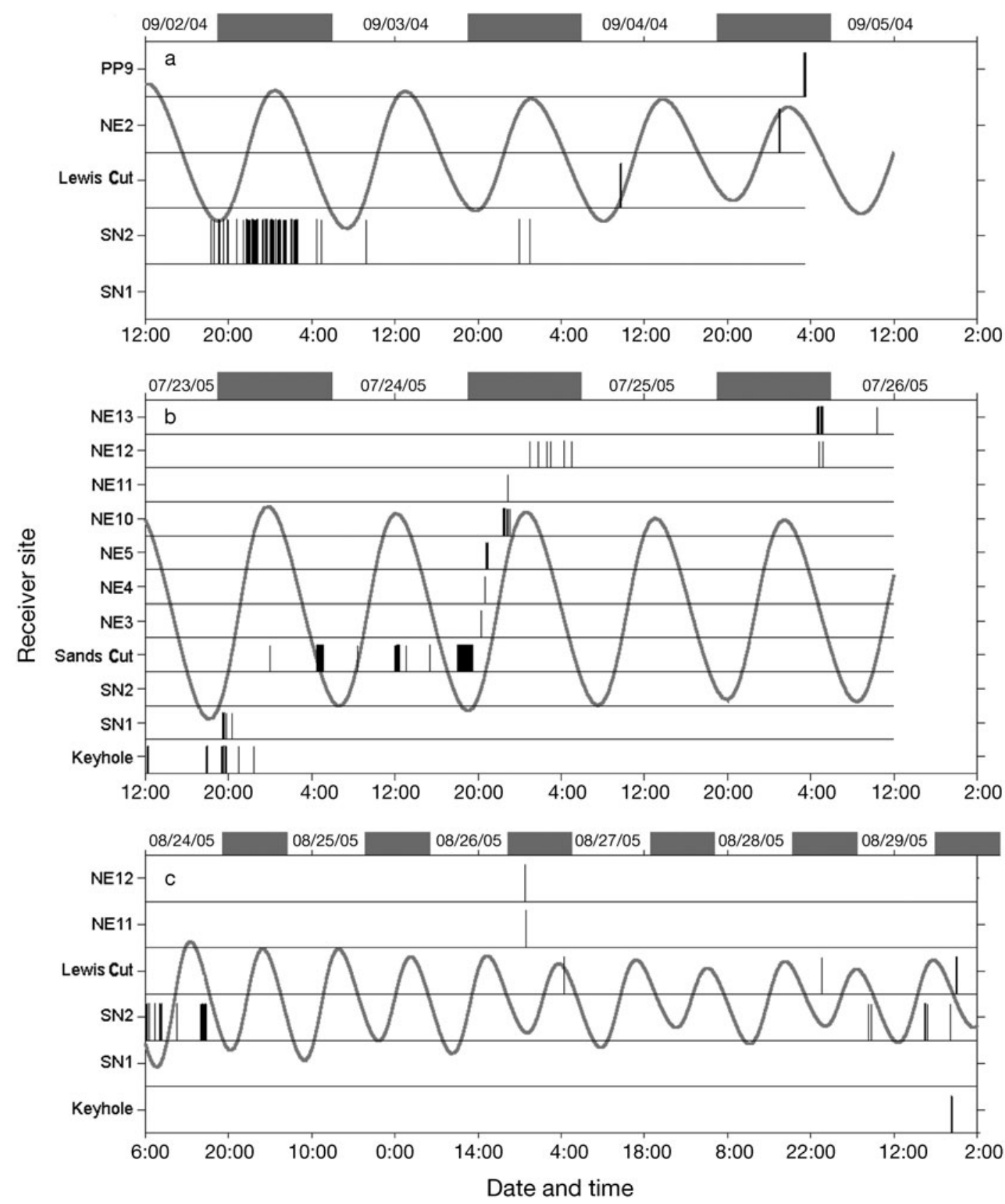

Fig. 4. Lutjanus griseus. Time series of acoustic signals from: (a) Fish 250, (b) Fish 211, and (c) Fish 214, detected by receivers of the automated acoustic telemetry system, indicating the offshore movement of gray snappers. Each discrete vertical mark indicates the time when the signal was detected by each receiver. Curved gray line: tidal phase at Sands Cut; gray bars: the time period from 19:00 to 6:00 h EST (mostly dark); dates given in format mm/dd/yy

cuts and channels have depth ranges of 2 to $5 \mathrm{~m}$. The distribution of depths occupied by a tagged snapper cannot be used to distinguish whether the fish was in mangrove and seagrass habitats of overlapping depth ranges, but it can reveal whether the fish was in deeper cuts and channels versus a very shallow area (such as a seagrass bed). The 6 tags revealed clear diel patterns of fish movement between the deep cuts and channels during the day and shallow areas during the night, which is consistent with recapture of these individuals at Sands Cut. For example, the fish with tag 3 was released at the mangrove shoreline near the Sands Cut on November 7, 2003 (Table 2). For the first $4 \mathrm{~d}$, the depths recorded by the fish were $<1 \mathrm{~m}$, consistent with the depth range of the man- 
Table 2. Lutjanus griseus. Recaptured gray snappers with archival tags. See Fig. 1 for release and recapture sites. Dates given in format $\mathrm{mm} / \mathrm{dd} / \mathrm{yy}$

\begin{tabular}{|c|c|c|c|c|c|c|c|c|}
\hline \multirow{2}{*}{$\begin{array}{l}\text { Fish } \\
\text { (tag no.) }\end{array}$} & \multicolumn{2}{|c|}{ Release } & \multicolumn{2}{|c|}{ Recapture } & \multirow{2}{*}{$\begin{array}{c}\text { Days at } \\
\text { large }\end{array}$} & \multirow{2}{*}{$\begin{array}{c}\text { Length } \\
\text { (cm) }\end{array}$} & \multirow{2}{*}{$\begin{array}{l}\text { Latitude } \\
\text { (degrees) }\end{array}$} & \multirow{2}{*}{$\begin{array}{l}\text { Longitude } \\
\text { (degrees) }\end{array}$} \\
\hline & Date & Site & Date & Site & & & & \\
\hline 3 & 11/07/03 & MG2 & $11 / 18 / 03$ & Sand Cut & 11 & 29.0 & 25.4924 & 80.1808 \\
\hline 9 & $11 / 20 / 03$ & MG2 & 04/09/04 & Sand Cut & 140 & 31.0 & 25.4909 & 80.1812 \\
\hline 4 & $12 / 01 / 03$ & MG2 & $04 / 17 / 04$ & Sand Cut & 137 & 28.5 & 25.4897 & 80.1813 \\
\hline 11 & $12 / 01 / 03$ & MG2 & $03 / 25 / 04$ & Sand Cut & 115 & 30.0 & 25.4897 & 80.1813 \\
\hline 14 & $12 / 15 / 03$ & MG1 & 03/07/04 & Sand Cut & 92 & 30.4 & 25.5065 & 80.1828 \\
\hline 17 & $12 / 15 / 03$ & MG1 & 05/29/04 & Sand Cut & 165 & 31.6 & 25.5065 & 80.1828 \\
\hline 24 & 05/05/04 & MG2 & $05 / 23 / 04$ & Sand Cut & 18 & 38.4 & 25.4936 & 80.1808 \\
\hline 41 & $10 / 06 / 04$ & MG2 & 04/20/06 & Reef & 561 & 31.0 & 25.4936 & 80.1801 \\
\hline
\end{tabular}

grove shoreline and nearby seagrass habitat (Fig. 5). On day 5 (November 11), the depth range increased from $<1$ to $>3 \mathrm{~m}$. Sands Cut is the only nearby location where the depth is $>2 \mathrm{~m}$. Thus, depth data suggest that the fish moved to the cut on day 5 and remained there until it was recaptured. While in the cut, the fish was able to swim up and down in the water column, recording depths from 0.2 to $4 \mathrm{~m}$. The ledges and cavities in the cut presumably serve a similar function as mangrove prop roots in providing shelter (protection from predators) for the snapper. Snapper appeared to swim around these ledges and cavities during the day and moved out to the surrounding shallow seagrass beds at night.

\section{Underwater video}

Although both video camera deployments encompassed different hours of the day, commonalities in fish behavior emerged (Fig. 6): snappers were detected in the mangroves at the daytime start of both deployments. The beginning and end of Deployments 1 and 2 indicate that snappers were detected in the mangroves from 8:30 to 16:00 h. At around 15:00 to $16: 30 \mathrm{~h}$, seagrass cameras detected snappers as they moved out of the mangroves and dispersed into the seagrass beds. Because seagrass cameras were positioned at the interface between mangrove and seagrass (i.e. at the seagrass fringe), no fish would be detected by these cameras while the fish were dispersed in the seagrass beds, only during their transition to and from the 2 habitats. Thus, no snappers were detected again by either set of cameras until around 6:00 to 9:00 h, when the seagrass cameras detected fish returning to the mangrove habitats. Deployment 1 reveals a distinct lag between snappers detected at the seagrass interface, and their subsequent detection in the mangroves between 8:30 and 14:00 h. Similarly, in Deployment 2, returning snappers were detected by the seagrass cameras until the deployment was terminated at 8:00 h (Fig. 6).

\section{DISCUSSION}

Despite its alternative common name of 'mangrove snapper', Lutjanus griseus is known to occur in a diversity of tropical and subtropical nearshore habitats, but its movement among these habitats is not well understood. We used a combination of tagging and video techniques to collect quantitative evidence of diel and seasonal movement of L. griseus among multiple habitats. A better understanding of the use of multiple habitats by $L$. griseus is a prerequisite for effective habitat-based management of this economically important species, especially in less-studied subtropical waters.

\section{Diel migrations}

All 3 fish monitoring techniques generated quantitative data on the diel movement of gray snapper among nearshore coastal habitats. The depth data from archival tags tracked the movement of snapper from their daytime occupancy of deeper cuts and channels to shallower habitats at night, although there was considerable variation among individuals as to the timing and extent of this behavior. The general similarity of water depths between most seagrass and mangrove habitats in the area constrained our interpretation of the archival tag data to only those fish that took refuge during the day in the ledges and cavities along the deeper cuts and channels. While the shallower depths at night may have included mangrove as well as seagrass habitats, the acoustic and video photographic data suggest that these shallower depths at night were most likely seagrass beds.

We obtained the most direct evidence of diel snapper movement among nearshore habitats from the acoustic tagging effort. Over 85000 individual acoustic detections from 14 tagged individuals demonstrated that fish were detected in seagrass areas near the receivers mostly during darkness (from $\sim 18: 00$ to $6: 00-8: 00 \mathrm{~h}$ ) 


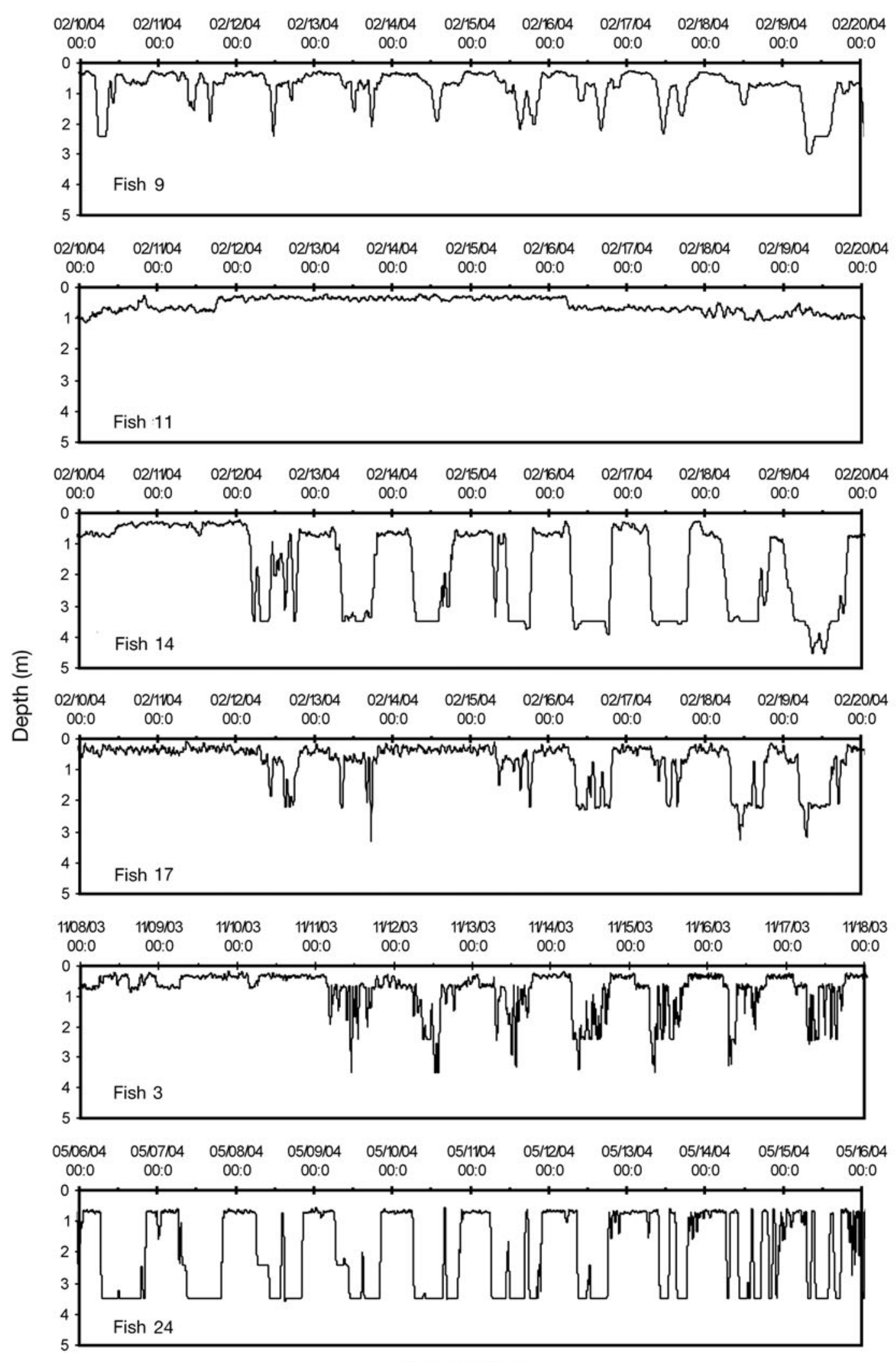

Date and time

Fig. 5. Lutjanus griseus. A sub-sample of 10 continuous days of depth records from 6 gray snappers implanted with archival tags. The same $10 \mathrm{~d}$ were plotted where possible. The first 4 records (Fish 9, 11, 14, 17) encompass the period from February 10 to 20 , 2004. The time period of deployment for the last 2 records (Fish 3 and 24) did not overlap with the others. Dates given in format $\mathrm{mm} / \mathrm{dd} / \mathrm{yy}$ 
and were less frequently detected during afternoon hours-a distinct $24 \mathrm{~h}$ periodicity in detections. The movement of fish from mangrove shorelines into seagrass beds closely matched the time of sunset; however, synchronization of their return with sunrise was less precise. Some seasonality in the specific timing of morning fish movement from the seagrass beds to mangroves was evident, with transitions more synchronized in the winter, becoming somewhat less distinct over time to a more gradual morning transition by

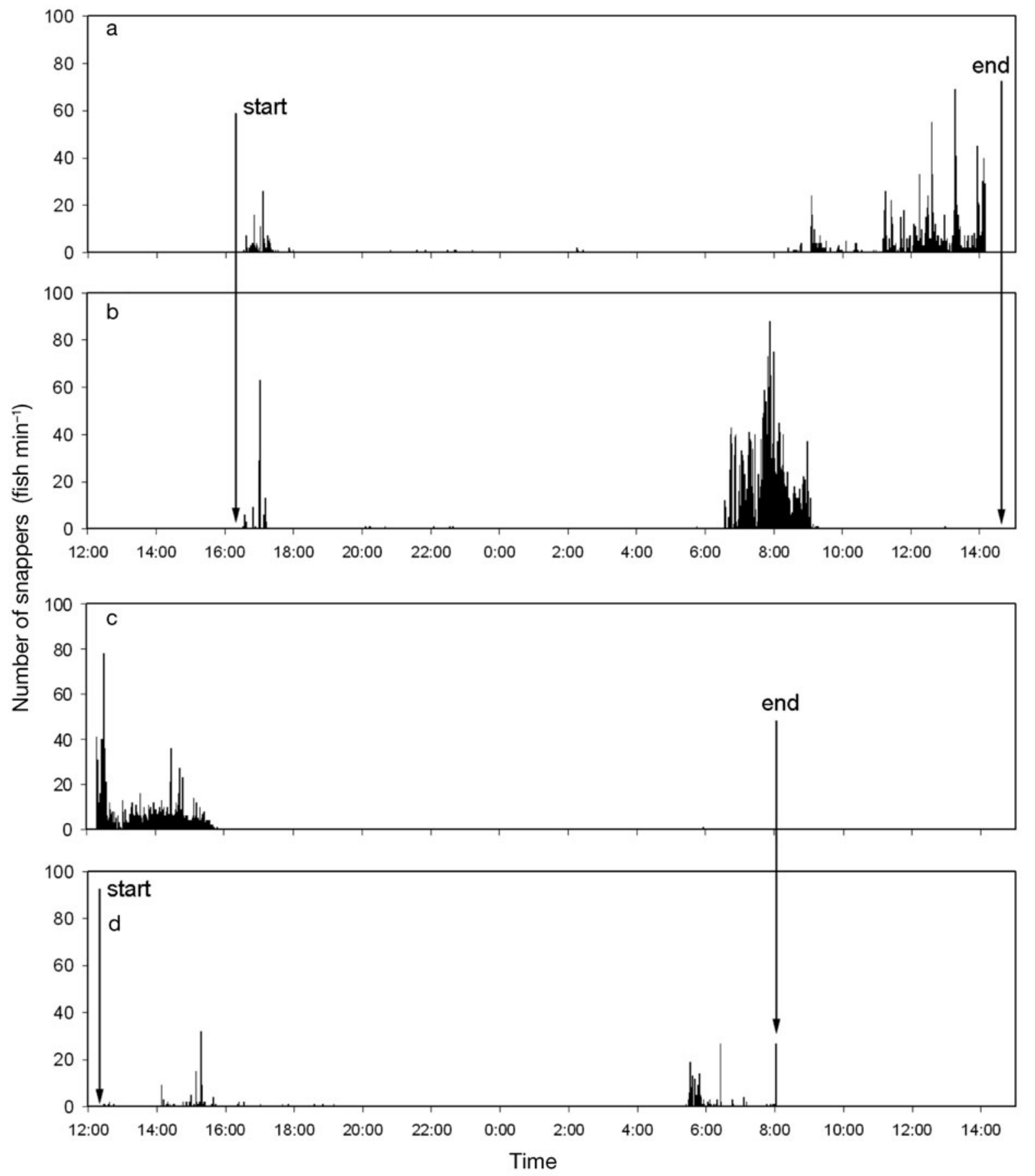

Fig. 6. Lutjanus griseus. Time series of the numbers of gray snapper detected by the underwater video system: Deployment 1 (on May 5 to 6, 2004), proximal to (a) mangrove and (b) seagrass habitats; Deployment 2 (May 10 to 11, 2005), proximal to (c) mangrove and (d) seagrass habitats. The start and end times for each year are indicated by the arrows 
fall. These observations on the timing of habitat transitions were confirmed by our underwater video monitoring. Fish were detected moving past the camera array during both time periods, with departure from the mangrove shoreline to the seagrass beds in the evening and arrival back to the mangroves in the morning. Return to the mangrove shorelines frequently extended into the late morning hours, as opposed to occurring exclusively between dusk and dawn, consistent with the results from acoustic tracking experiments.

Diel movement between nearshore habitats by snapper is primarily related to foraging. Gut content analysis has previously confirmed that lutjanids are nocturnal foragers, and seagrass beds have been found to harbor higher densities of their preferred prey (tanaid and decapod crustaceans; Nagelkerken et al. 2000). Nocturnal foraging by gray snapper also may minimize their risk of predation (Starck \& Davis 1966). After foraging, gray snappers are thought to return to and shelter in resting schools in complex habitats such as mangrove prop roots (Rooker \& Dennis 1991) or patch reefs (Ogden \& Ehrlich 1977) during the daytime to reduce predation risk. The importance of the light/dark cycle in cueing movement (McFarland et al. 1979) might be expected to cause some shifting in fish behavior in association with seasonal shifts in the timing of sunset/sunrise.

Diel movement of Lutjanus griseus among nearshore habitats has important ramifications for population abundance surveys. Sampling in mangrove prop roots or in seagrass beds would yield distinctly different results if conducted at different times of the day. Grunts (Haemulidae) are also thought to undergo similar diel migrations into seagrass beds at night (Ogden \& Ehrlich 1977, Baelde 1990). Acoustic tracking allowed us to minimize the bias inherent in more typical daytime sampling, particularly in visual surveys.

\section{Bay-to-ocean movement}

Acoustic tags also revealed occasional movement of gray snapper from inshore habitats to offshore reef habitats, particularly during the reproductive season of this species. Of the 14 tagged fish detected during the study, 7 fish were detected by receivers located at bay-to-ocean passes, and 3 of these were also detected by receivers positioned offshore in reef habitat, indicating that at least $21 \%$ of the snappers moved between the bay and ocean. Importantly, fish that were not detected by offshore receivers did not necessarily remain exclusively inshore. There are numerous ways for fish to move between the bay and reef and avoid detection by our receivers. Of the 7 fish that went undetected by the receivers in the passes, 4 left the vicinity of MG1 in <15 d. We cannot exclude the possibility that these fish moved offshore via a bay-to-ocean pathway that was not monitored by our receivers. Three fish released in November remained at MG1 until their tag batteries failed in April (before the migration season). The offshore receivers cannot detect all fish moving offshore. The acoustic fence was designed to detect fish moving north and south; a third fence, stretching east to west would have been optimal, but was beyond our resources. If a tagged fish moved offshore without crossing one of the fences, it would not be detected. The fact that the 3 fish tagged at the reef site were never detected by any of the receivers illustrates this possibility. Thus, despite our relatively small sample size of tagged Lutjanus griseus, 50\% were detected at the passes and $21 \%$ were detected by offshore receivers. Connectivity among mangrove, seagrass, and reef habitats was recently demonstrated for a congener, the schoolmaster snapper L. apodus (Verweij et al. 2007). The largest 4 of $59(\sim 7 \%)$ conventionally tagged sub-adult $L$. apodus were observed (visually) 30 to $90 \mathrm{~m}$ away in a neighboring coral reef in Curacao. The 3 bay-to-reef migrations that we documented encompassed movements within $\sim 10 \mathrm{~km}$, with a maximum documented transit of $15 \mathrm{~km}$ for 1 acoustically tagged L. griseus. Mass spawning aggregation sites for a number of snapper species have been identified in the lower Florida Keys (Lindeman et al. 2000), and it is likely that other such sites exist along the upper Florida Keys. We hypothesize that the long reef-directed migrations that we detected were associated with movement to these spawning sites.

It is noteworthy that all migrations to and from the reef occurred at night. The specific timing of movement between receiving stations can only be discerned where detections occurred at neighboring stations over relatively short time periods. All of the 3 tagged fish (Fish 211, 214, and 250) that displayed bay-toocean movement swam between the reef and mangrove habitats at night at speeds of 1.1 to $2.8 \mathrm{BL} \mathrm{s}^{-1}$, roughly comparable to the swimming speeds $(0.7$ to 2.0 $\mathrm{BL} \mathrm{s}^{-1}$ ) estimated from a laser-video system (J. Luo unpubl. data). Perhaps coincidentally, the most rapid movement that we measured (i.e. Fish 250) was for a fish at-large prior to and during the passage of Hurricane Frances, which was centered about $100 \mathrm{~km}$ to the north of our study area. It is possible the rapid movement offshore by Fish 250 was similar to the inshore-offshore movements of tagged blacktip sharks Carcharhinus limbatus in response to a tropical storm off the west coast of Florida (Heupel et al. 2003) and of red snapper Lutjanus campechanus during hurricanes in the Gulf of Mexico (Patterson et al. 2001). 


\section{Management implications}

Our study demonstrates biological connectivity among the multiple nearshore habitats of seagrass, mangrove, and coral reefs in subtropical waters and corroborates others that recommend greater emphasis on the conservation of nearshore habitats in tandem with protection of the reef proper. Direct measurement of the utilization of all 3 habitats by gray snapper is important for monitoring and managing the resource and especially for evaluating the efficacy of current or future spatial fishing closures or other management actions. Questions surrounding the scale, configuration, and efficacy of spatial fishing closures are best addressed with knowledge gleaned via tagging studies. However, although the expense of tagging technology is declining, costs in terms of equipment and especially manpower continue to be substantial when quantifying fish movement in large open systems. Despite the small sample sizes that are typical of electronic tagging studies in open marine systems, only through continued investment in investigations of this type will the empirical basis for spatial management planning emerge.

Acknowledgements. Funding of the project was provided by the National Sea Grant Essential Fish Habitat Program with matching funds from Jerry Lorenz of the National Audubon Society and funds from NOAA CRCP. We are grateful to M. Larkin and J. Ault for their collaborative efforts with the automated acoustic telemetry system. We thank many volunteers who participated in tagging gray snapper, and the anglers who returned the conventional and the archival tags.

\section{LITERATURE CITED}

Adams AJ, Dahlgren CP, Kellison GT, Kendall MS and others (2006) Nursery function of tropical back-reef systems. Mar Ecol Prog Ser 318:287-301

Ault JS, Bohnsack JA, Meester GA (1998) A retrospective (1979-1996) multispecies assessment of coral reef fish stocks in the Florida Keys. Fish Bull (Wash DC) 96: 395-414

Baelde P (1990) Differences in the structures of fish assemblages in Thalassia testudinium beds in Guadeloupe, French West Indies, and their ecological significance. Mar Biol 105:163-173

Beck MW, Heck KL Jr, Able KW, Childers DL and others (2001) The identification, conservation, and management of estuarine and marine nurseries for fish and invertebrates. Bioscience 51:633-641

Bohnsack JA, McClellan DB, Douglas EH, Davenport GS and others (1999) Baseline data for evaluating reef fish populations in the Florida Keys, 1979-1998. NOAA Tech Memo NMFS-SEFSC-427, Miami, FL

Bohnsack JA, Ault JS (1996) Management strategies to conserve marine biodiversity. Oceanography 9:73-82

Chittaro PM, Fryer BJ, Sale PF (2004) Discrimination of French grunts (Haemulon flavolineatum Desmarest, 1823) from mangrove and coral reef habitats using otolith microchemistry. J Exp Mar Biol Ecol 308:169-183

Cocheret de la Moriniére E, Pullux BJA, Nagelkerken I, van der Velde G (2002) Post-settlement life cycle migration patterns and habitat preference of coral reef fishes that use seagrass and mangrove habitats as nurseries. Estuar Coast Shelf Sci 55:309-321

Cocheret de la Moriniére E, Pullux BJA, Nagelkerken I, Hemminga MA, Huiskes AHL, van der Velde G (2003) Ontogenetic dietary changes of coral reef fishes in the mangroveseagrass-reef continuum: stable isotopes and gut-content analysis. Mar Ecol Prog Ser 246:279-289

Dorenbosch M, Verbeck WCEP, Nagelkerken I, van der Velde G (2007) Influence of habitat configuration on connectivity between fish assemblages of Caribbean seagrass beds, mangroves and coral reefs. Mar Ecol Prog Ser 334: 103-106

Faunce CH, Serafy JE (2006) Mangroves as fish habitat: 50 years of field studies. Mar Ecol Prog Ser 318:1-18

Faunce CH, Serafy JE (2007) Nearshore habitat use by gray snapper (Lutjanus griseus) and bluestripped grunt (Haemulon sciurus): environmental gradients and ontogenetic shifts. Bull Mar Sci 80:473-495

Harrigan P, Zieman JC, Macko SA (1989) The base of nutritional support for the gray snapper (Lutjanus griseus): an evaluation based on a combined stomach content and stable isotope analysis. Bull Mar Sci 44:65-77

Heupel MR, Simpfendorfer CA, Hueter RE (2003) Running before the storm: blacktip sharks respond to falling barometric pressure associated with tropical storm Gabrielle. J Fish Biol 63:1357-1363

> Heupel MR, Semmens JM, Hobday AJ (2006) Automated acoustic tracking of aquatic animals: scales, design and deployment of listening station arrays. Mar Freshw Res 57: $1-13$

> Jorgensen SJ, Kaplan DM, Klimley AP, Morgan SG, O'Farrell MR, Botsford LW (2006) Limited movement in blue rockfish Sebastes mystinus: internal structure of home range. Mar Ecol Prog Ser 327:157-170

> Laegdsgaard P, Johnson CR (2001) Why do juvenile fish utilize mangrove habitats? J Exp Mar Biol Ecol 257:229-253

Larkin MF, Ault JS, Humston R, Luo J, Zurcher N (2008) Tagging of bonefish in South Florida to study population movements and stock dynamics. In: Ault JS (ed) Biology and management of the world tarpon and bonefish fisheries. CRC Series in Marine Science, Taylor \& Francis Group, Oxford, p 301-320

Ley JA, McIvor CC (2002) Linkages between estuarine and reef fish assemblages: enhancement by the presence of well-developed mangrove shorelines. In: Porter JW, Porter KG (eds) The Everglades, Florida Bay and coral reefs of the Florida Keys: an ecosystem sourcebook. CRC Press, Boca Raton, FL, p 539-562

Lindeman KC, Pugliese R, Wagh GT, Ault JS (2000) Developmental patterns within a multispecies reef fishery: management applications for essential fish habitats and protected areas. Bull Mar Sci 66:929-956

Marty GD, Summerfelt RC (1986) Pathways and mechanisms for expulsion of surgically implanted dummy transmitters from channel catfish. Trans Am Fish Soc 115:577-589

> McFarland WN, Ogden JC, Lythgoe JN (1979) The influence of light on the twilight migrations of grunts. Environ Biol Fishes 4:9-22

> Meyer CG, Holland KN, Papastamatiou YP (2007) Seasonal and diel movements of giant trevally Caranx ignobilis at remote Hawaiian atolls: implications for the design of marine protected areas. Mar Ecol Prog Ser 333:13-25 
Mumby PJ, Edwards AJ, Arias-Gonzalez JE, Lindeman KC and others (2004) Mangroves enhance the biomass of coral reef fish communicates in the Caribbean. Nature 427: 533-536

Nagelkerken I (2007) Are non-estuarine mangroves connected to coral reefs through fish migration? Bull Mar Sci 80:595-607

Nagelkerken I, Dorenbosch M, Verberk WCEP, Cocheret de la Moriniére E, van der Velde G (2000) Day-night shifts of fishes between shallow-water biotopes of a Caribbean bay, with emphasis on the nocturnal feeding of Haemulidae and Lutjanidae. Mar Ecol Prog Ser 194:55-64

> Nagelkerken I, Blaber SJM, Bouillon S, Greene P and others (2008) The habitat function of mangroves for terrestrial and marine fauna: a review. Aquat Bot 89:155-185

Ogden JC (1997) Ecosystem interactions in the tropical coastal seascape, Chapter 13. In: Birkeland J (ed) Life and death of coral reefs. Chapman-Hall Science, New York, p 288-296

> Ogden JC, Ehrlich PR (1977) The behavior of heterotypic resting schools of juvenile grunts (Pomadasyidae). Mar Biol 42:273-280

> Orth RJ, Heck KL, van Montfrans J (1984) Faunal communities in seagrass beds: a review of the influence of plant structure and prey characteristics on predator-prey relationships. Estuaries 7:339-350

Patterson WFIII, Waterson JC, Shipp RL, Cowan JH Jr (2001) Movement of tagged red snapper in the northern Gulf of Mexico. Trans Am Fish Soc 130:533-545

Robblee MB, Zieman JC (1984) Diel variation in the fish fauna of a tropical seagrass feeding ground. Bull Mar Sci 34: $335-345$

Rooker JR, Dennis GD (1991) Diel, lunar and seasonal changes in a mangrove fish assemblage of southwestern Puerto Rico. Bull Mar Sci 49:684-689

Editorial responsibility: Kenneth Heck, Dauphin Island, Alabama, USA
Sedberry GR, Carter J (1993) The fish community of a shallow tropical lagoon in Belize, Central America. Estuaries 16:198-215

> Serafy JE, Lindeman KC, Hopkins TE, Ault JS (1997) Effects of freshwater canal discharge on fish assemblages in a subtropical bay: field and laboratory observations. Mar Ecol Prog Ser 160:161-172

Serafy JE, Faunce CH, Lorenz JJ (2003) Mangrove shoreline fishes of Biscayne Bay, Florida. Bull Mar Sci 72:161-180

Serafy JE, Valle M, Faunce CH, Luo J (2007) Species-specific patterns of fish size and abundance along a subtropical mangrove shoreline: application of the delta approach. Bull Mar Sci 80:609-624

Sheridan P, Hays C (2003) Are mangroves nursery habitat for transient fishes and decapods? Wetlands 23:449-458

Starck WA II (1971) Biology of the gray snapper, Lutjanus griseus (Linnaeus) in the Florida Keys. In: Starck WA, Schroeder RE (eds) Investigations on the gray snapper. University of Miami Press, Coral Gables, FL, p 13-150

Starck WA II, Davis WP (1966) Night habits of fishes of Alligator Reef, Florida. Ichthyol Aquar J 38:313-356

Taylor MD, Laffan SD, Fielder DS, Suthers IM (2006) Key habitat and home range of mulloway Argyrosomus japonicus in a south-east Australian estuary: finding the estuarine niche to optimize stocking. Mar Ecol Prog Ser 328:237-247

Verweij MC, Nagelkerken I, Hol KEM, van den Beld AHJB, van der Velde G (2007) Space use of Lutjanus apodus including movement between a putative nursery and a coral reef. Bull Mar Sci 81:127-138

> Weinstein MP, Heck KL (1979) Ichthyofauna of seagrass meadows along the Caribbean coast of Panama and in the Gulf of Mexico: composition, structure and community ecology. Mar Biol 50:97-107

Winter JD (1983) Underwater biotelemetry. In: Nielsen LA, Johnson DL (eds) Fisheries techniques. American Fisheries Society, Bethesda, MD, p 371-395

Submitted: April 23, 2008; Accepted: December 23, 2008 Proofs received from author(s): March 26, 2009 